\title{
Morphology and reproduction of Mesophyllum erubescens (Foslie) Me. Lemoine (Corallinales, Rhodophyta) from Southern Brazil
}

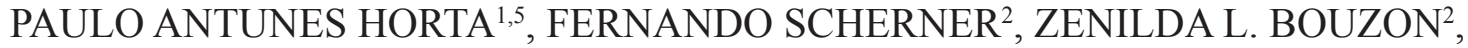 \\ RAFAEL RIOSMENA-RODRIGUES ${ }^{3}$ and EURICO C. OLIVEIRA ${ }^{4}$
}

(received: July 04, 2007; accepted: February 23, 2011)

\begin{abstract}
Morphology and reproduction of Mesophyllum erubescens (Foslie) Me. Lemoine (Corallinales, Rhodophyta) from Southern Brazil). The genus Mesophyllum Me. Lemoine includes around 147 species, of which only three have been referred to the Brazilian coast. Mesophyllum erubescens was originally described from Fernando de Noronha Archipelago, Brazil (type locality). Here we present the first detailed description of M. erubescens based on Brazilian material. Samplings were made through scuba diving at the Biological Marine Reserve of Arvoredo Island, Santa Catarina. The relations of M. erubescens with other similar species, especially from the American Atlantic studied by W.R. Taylor are discussed.
\end{abstract}

Key-words - Arvoredo Island, mäerl, rhodolith bed, seaweed taxonomy

RESUMO - (Morfologia e reprodução de Mesophyllum erubescens (Foslie) Me. Lemoine (Corallinales, Rhodophyta) do Sul do Brasil). O gênero Mesophyllum Me. Lemoine compreende cerca de 147 espécies, das quais apenas três são referidas para a costa brasileira. Mesophyllum erubescens foi originalmente descrita para o Arquipélago de Fernando de Noronha, Brasil (localidade tipo). Neste trabalho é apresentada a primeira descrição detalhada de M. erubescens baseada em material brasileiro. As amostragens foram realizadas através de mergulho autônomo na Reserva Biológica Marinha do Arvoredo, Santa Catarina. As relações de M. erubescens com outras espécies semelhantes são discutidas, sendo especialmente consideradas espécies do Atlântico Americano estudadas por W.R. Taylor.

Palavras-chave - banco de rodolitos, Ilha do Arvoredo, mäerl, taxonomia de macroalgas

\section{Introduction}

Of the 23 infrageneric taxa of nongeniculate corallines referred to Brazil, eight species belong to the subfamily Melobesioideae, distributed in four genera: Lithothamnion Heydrich, Melobesia Lamouroux, Mesophyllum Lemoine and Phymatolithon Foslie (Horta 2002, Tâmega \& Figueiredo 2005). Although Mesophyllum taxonomy has been dealt with by several authors (Woelkerling \& Harvey 1992, Keats \& Maneveldt 1997, Cabioch \& Mendoza 1998, Chamberlain 2000, Ringeltaube \& Harvey 2000, Harvey et al. 2003, Athanasiadis et al. 2004, Kim et al. 2004), there are few detailed accounts of this genus for the western Atlantic and most of them do not include data on reproductive structures (Taylor 1960, Littler \& Littler 2000). According to Athanasiadis et al. (2004) this genus can be distinguished from other

1. Universidade Federal de Santa Catarina, Departamento de Botânica, Caixa Postal 476, 88010-970 Florianópolis, SC, Brazil.

2. Universidade Federal de Santa Catarina, Departamento de Biologia, Caixa Postal 476, 88049-900 Florianópolis, SC, Brazil.

3. Universidad Autónoma de Baja California Sur, Departamento de Biologia Marina, Programa de Investigación en Botánica Marina. Apartado postal 19-B, km 5.5. Carretera al sur. La Paz B.C.S. 23080, Mexico.

4. Universidade de São Paulo, Instituto de Biociências, Departamento de Botânica, Caixa Postal 11461, 05422-970 São Paulo, SP, Brazil.

5._Corresponding author: pahorta@ccb.ufsc.br. similar Melobesioideae by the presence of a coaxial hypothallium, unbranched spermatangial structure and the dumbbell-shaped carposporangial chambers.

Mesophyllum erubescens (Foslie) Me. Lemoine was first reported by Dickie (1874) to Fernando de Noronha Archipelago as Lithothamnion mamillare Harvey, which also appeared in the lists of Brazilian algae published by Hemsley (1885) and Murray (1893). Oliveira Filho (1974), examining Dickie's material deposited at the British Museum (Natural History), refers to this species as Goniolithon mamillare (Harvey) Foslie, based on the synonymy proposed by Taylor (1960), while Oliveira Filho (1977) refers to it as Neogoniolithon mamillare (Harvey) Foslie. Foslie (1900) classified this species as Lithothamnion erubescens Foslie f. americana Foslie, which in accordance to Woelkerling (1993) is superfluous for L. erubescens Foslie f. erubescens. M. Lemoine (1928) considered this material as part of the new genus Mesophyllum, which was accepted by Adey (1970) and Woelkerling (1988). This species was recently referred to Brazil by Figueiredo \& Steneck (2002), Pereira et al. (2002), Villaça et al. (2006) and Nunes et al. (2008).

Here we provide a detailed description of $M$. erubescens based on specimens collected for the first time in southern Brazil, belonging to a warm temperate province (Horta et al. 2001) and located at more than 
4,000 km south from its type locality. Additionally, we compare our specimens with other similar taxa described to the Atlantic Ocean by Taylor (1960) and kept at the Michigan Herbarium. Due to the importance of the referred work to the western Atlantic, these analysis are necessary to verify whether the Taylor identifications can be sustained according to the most recent diagnostic characteristics and nomenclature (Athanasiadis et al. 2004, Broom et al. 2008).

\section{Material and methods}

Collections were made at the Arvoredo Island, Santa Catarina state $\left(27^{\circ} 17,50^{\prime} \mathrm{S}, 48^{\circ} 22,00^{\prime} \mathrm{W}\right)$ with scuba diving. For optical microscopy decalcification was made with $45 \%$ acetic acid for 5-24 hours, followed by dehydration with ethanolic series, infiltration and inclusion in "Historesin embedding Kit" Leica, Reichert-Jung, according to the instructions supplied by the manufacturer. Sectioning (3$15 \mu \mathrm{m}$ thick) was made with a Leica microtome (model 2040), stained with acidified aqueous toluidine blue (Moura et al. 1997). The studied specimens were deposited at the Phycological Herbarium of the Federal University of Santa Catarina (FLOR). (BRASIL: Santa Catarina: Arvoredo Island, P. Horta, 23-VI-2001, 10-I-2002, 07-VI-2002 (FLOR 14337, $14508,14509)$ ). The additional material analyzed from the Taylor's collections was deposited at University of Michigan
Herbarium (United States: Florida: Keywest, Monroe, VIII-1939, (MICH 18340) and Bermuda, Farlow, without collector, V-1901, (MICH - without number)) were chosen due to the similar morphology, presence of protuberance with 1-2 $\mathrm{mm}$ in diameter. Techniques for scanning electron microscopy followed Chamberlain (1993).

\section{Results}

Mesophyllum erubescens (Foslie) Me. Lemoine 1928:252.

Basyonym: Lithothamnion erubescens Foslie 1900:9-10, Taylor (1960).

Cited as Lithothamnion mamillare Harvey, Dickie (1874), Hemsley (1885), Murray (1893); Goniolithon mamillare (Harvey) Foslie sensu Oliveira Filho (1974); Neogoniolithon mamillare (Harvey) Foslie sensu Oliveira Filho (1977); Lithothamnion incertum Foslie sensu Foslie (1904), Taylor (1960).

Mesophyllum erubescens from Santa Catarina - Habitat and gross morphology: this species is common and sometimes abundant in the studied area, forming a rhodolith bed in association with species of Lithophyllum and Lithothamnion from 7 to 16 meters depth. Thallus violet brown, unattached, ranging from individual to globoid branched masses, up to $18 \mathrm{~cm}$ in diameter; protuberances often branched, initially cylindrical to slightly flattened, $1-3 \mathrm{~mm}$ in diameter and 2-7 mm long, with frequent fusions (figures 1-3).
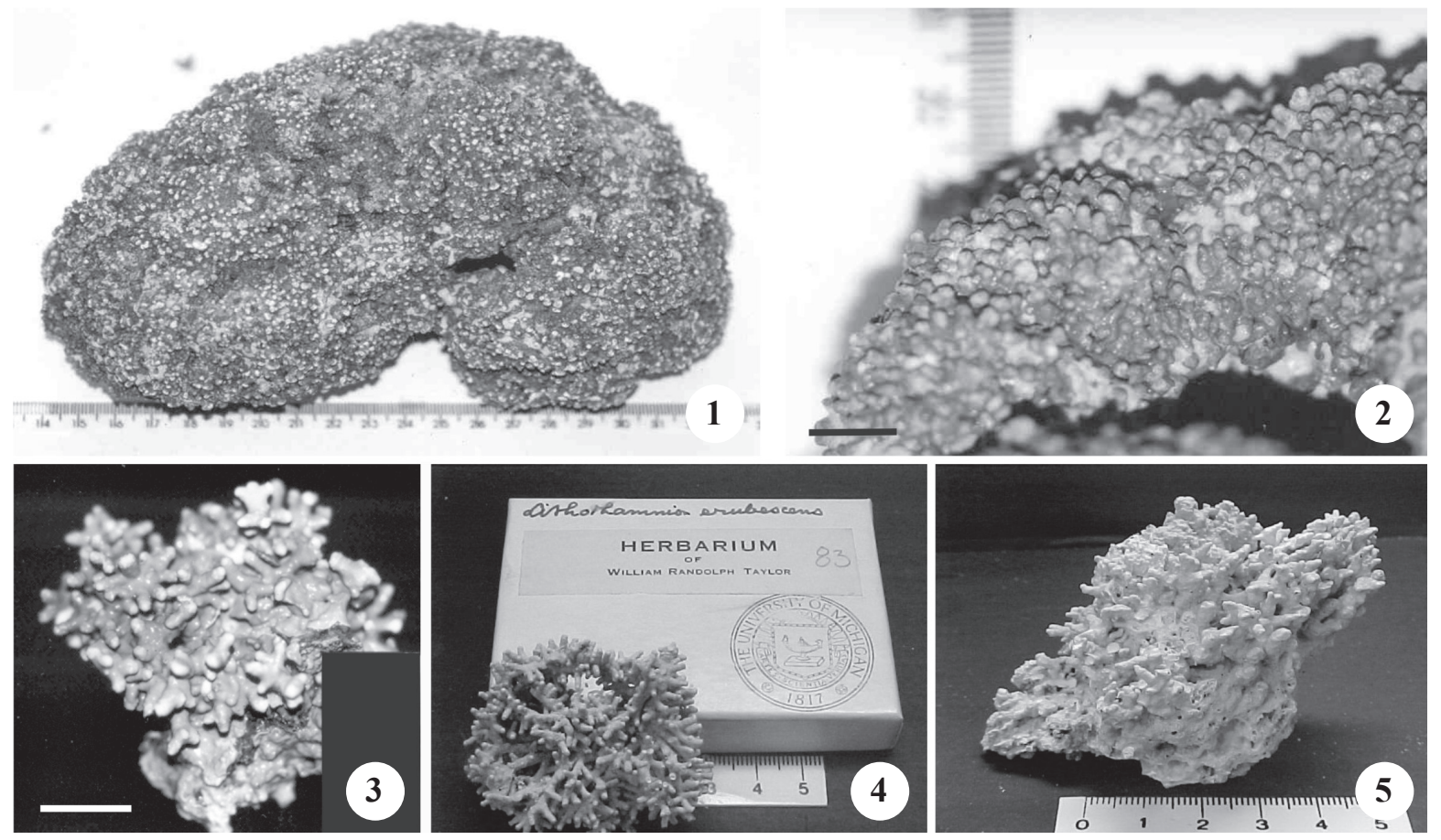

Figures 1-5. General aspects of Mesophyllum studied species: 1-3. Mesophyllum erubescens from Arvoredo Island. 2. and 3. Different aspects of protuberances (FLOR 14337 and 14508, respectively). 4. MICH 18340, as Lithothamnium erubescens from Taylor's Herbarium, from Florida. 5. MICH s.n., as Lithotyhamnion incertum from Bermuda. Bar = $0.75 \mathrm{~cm}(2) ; 1 \mathrm{~cm}(3)$. 
Anatomy: crustose structure monomerous with cells of hipothallial filaments strongly coaxial, 14-21 $\mu \mathrm{m}$ long and 5-8 $\mu \mathrm{m}$ in diameter; cells of perithallial filaments 9-15 $\mu \mathrm{m}$ long and $4-7 \mu \mathrm{m}$ in diameter. Protuberances with medullary cylindrical cells 11-20 $\mu \mathrm{m}$ long and 3-6 $\mu \mathrm{m}$ in diameter; cortical cylindrical cells 14-21 $\mu \mathrm{m}$ long and 5-8 $\mu \mathrm{m}$ in diameter. Subepithallial initial cells markedly longer than the subtending ones, 8-15 $\mu \mathrm{m}$ long and 3-6 $\mu \mathrm{m}$ in diameter.
Epithallial cells single, rounded to oval, 2-4 $\mu \mathrm{m}$ long and 4-9 $\mu \mathrm{m}$ in diameter; isolated trichocytes present; sloughing of epithallial cells frequent. Epithallial cells "Phymatolithon-type" in SEM view (sensu Keats \& Chamberlain 1994). Adjacent filaments joined by cell fusions. Secondary pit connection not observed (figures 6-8).

Reproduction: tetrasporangial conceptacle multiporate, protruding but flattened at the roof, without
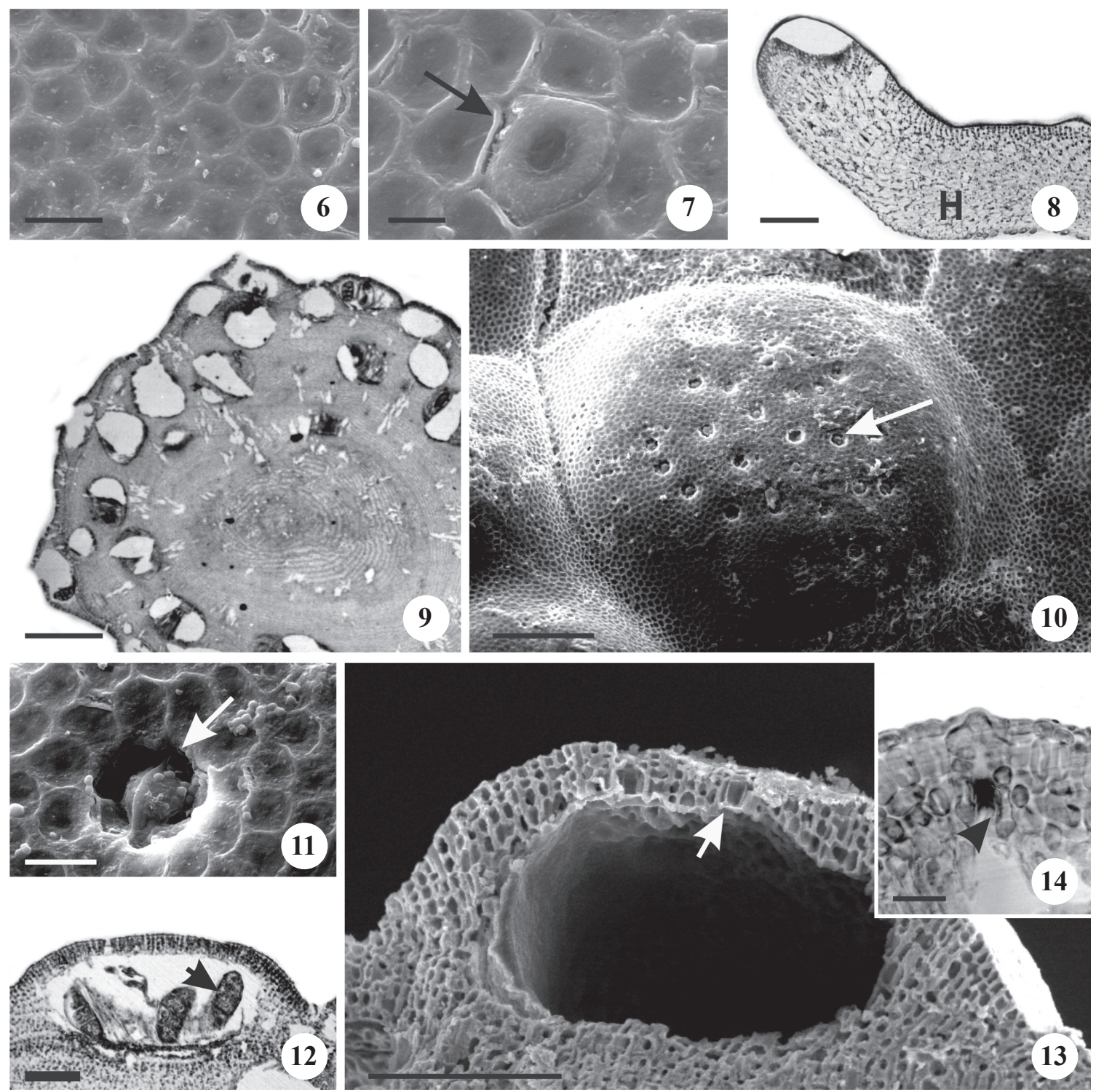

Figures 6-14. Optical and SEM micrographs of Mesophyllum erubescens from Arvoredo Island (FLOR 14509). 6. Epithallial cells in surface view $(B a r=10 \mu \mathrm{m})$. 7. Trichocytes in surface view (arrow) $(\mathrm{Bar}=5 \mu \mathrm{m}) .8$. Transversal section of the thallus margin showing coaxial hypothallium $(\mathrm{H})(\mathrm{Bar}=60 \mu \mathrm{m})$. 9. Transversal section of a protuberance showing buried conceptacles $(B a r=300 \mu \mathrm{m}) .10$. Tetrasporangial conceptacles in surface view, showing pores (arrow) $(B a r=100 \mu \mathrm{m}) .11$. Tetrasporangial pore detail (arrow) $(\mathrm{Bar}=10 \mu \mathrm{m})$. 12. Conventional light microscopy of tetrasporangial conceptacles with zonate tetrasporangia in transversal section $(B a r=50 \mu \mathrm{m})$. 13. SEM view of tetrasporangial conceptacles in transversal section, showing pores (arrow) $(B a r=100 \mu \mathrm{m})$. 14. Detail of tetrasporangial conceptacle roof with pore canal with elongated cell at the base (arrow head) in transversal section $(\operatorname{Bar}=15 \mu \mathrm{m})$. 
differentiation into a peripheral rim and a central, sunken pore plate; chambers elliptical $84-153 \mu \mathrm{m}$ high and 254$551 \mu \mathrm{m}$ broad, with roof or pore plate $35-45 \mu \mathrm{m}$ thick composed of 5-7-celled filaments of rounded cells; pore canals lined by 3-4 celled filaments with a basal cell 12-14 $\mu \mathrm{m}$ long and 3-4 $\mu \mathrm{m}$ in diameter, longer than other roof cells. Tetrasporangia scattered across the conceptacle chamber floor, transversally divided; each mature sporangium, 33-118 $\mu \mathrm{m}$ long and 33-76 $\mu \mathrm{m}$ in diameter, presents an apical plug that blocks a roof pore prior to spore release. Gametangial thallus monoecious. Carpogonial conceptacle flattened and carpogonial branch with two cells; carposporangial conceptacle uniporate, dumbbell-shaped and markedly raised; chamber 151-265 $\mu \mathrm{m}$ high and 213-457 $\mu \mathrm{m}$ diameter; roof $72-104 \mu \mathrm{m}$ thick, with cells projected into the poor canal; fusion cell fragmentary with gonimoblast filaments mainly at the periphery but also over the chamber floor; carpospores elliptical, $25-68 \mu \mathrm{m}$ in diameter. Spermatangial conceptacle uniporate, slightly raised in relation to the surrounding surface; chambers domed 40-182 $\mu \mathrm{m}$ high and 162-508 $\mu \mathrm{m}$ broad; roof 41-99 $\mu \mathrm{m}$ thick; pore with cells projected into the canal; spermatangial systems simple on the floor walls and roof of the chamber; spermatangia arising from a conical cell 8-13 $\mu \mathrm{m}$ long and 3-6 $\mu \mathrm{m}$ in diameter subtended by subconical cells at the chamber floor and from a sausageshape cell 6-10 $\mu \mathrm{m}$ long and 3-4 $\mu \mathrm{m}$ in diameter on the roof (figures 9-20).

Description of specimens in W. R. Taylor's herbarium MICH 18340 (originally identified as Lithothamnion erubescens Foslie) from Florida was represented by a fruticose rhodolith, with $4.5 \mathrm{~cm}$ in diameter; protuberances cylindrical to slightly flattened, 1-3 mm in diameter and 5-25 mm long, subdichotomously branched, with frequent branch fusions. Epithallial cells like "Leptophython-type". Protuberances with medullary
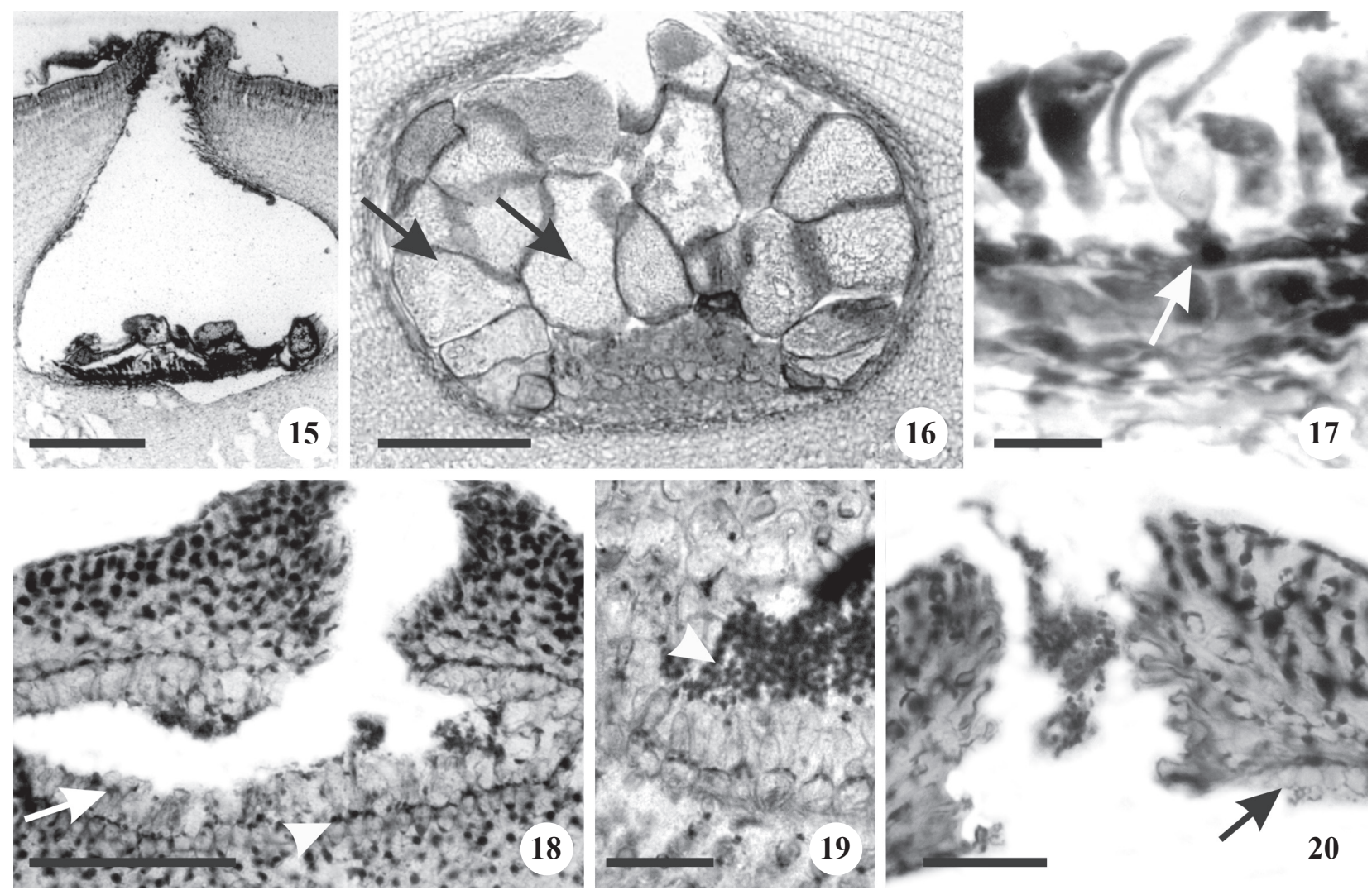

Figures 15-20. Anatomical aspects of gametangial conceptacles of Mesophyllum erubescens from Arvoredo Island, using light microscope images (FLOR 14337). 15. Section of uniporated carposporophyte conceptacle $(\mathrm{Bar}=100 \mu \mathrm{m})$. 16. Detail of carpospores (arrows) $($ Bar $=50 \mu \mathrm{m})$. 17. Detail of carpogonial filaments, showing fusion cell (arrow) $($ Bar $=10 \mu \mathrm{m})$. 18. Section of male conceptacle with spermatangial filaments arising from the floor and roof, showing on the floor elongated spermatangial initial (arrow) subtended by subconical cells (arrow head) $(B a r=50 \mu \mathrm{m})$. 19. Detail of unbranched spermatangial filaments (arrow head) $(\mathrm{Bar}=10 \mu \mathrm{m})$. 20. Detail of pore of male conceptacle with elongated spermatangial initial (arrow) on the roof of the chamber $(\mathrm{Bar}=20 \mu \mathrm{m})$. 
filament cells $14-30 \mu \mathrm{m}$ long and 5-14 $\mu \mathrm{m}$ in diameter and cells of cortical filaments 5-23 $\mu \mathrm{m}$ long and 5-14 $\mu \mathrm{m}$ in diameter; subepithallial initial cells markedly longer than the subtending ones, 12-21 $\mu \mathrm{m}$ long and 5-9 $\mu \mathrm{m}$ in diameter. Epithallial cells single, oval, 2-3 $\mu \mathrm{m}$ long and $5-8 \mu \mathrm{m}$ in diameter; isolated trichocytes present. Adjacent filaments joined by cell fusions. Secondary pit connections were not observed. Uniporated conceptacles markedly raised; chamber dumbbell-shaped with
151-265 $\mu \mathrm{m}$ height and 213-457 $\mu \mathrm{m}$ in diameter; roof 72-104 $\mu \mathrm{m}$ thick, pore with cells projected into the canal. Male and female structures were not observed because the conceptacles were empty. Multiporated conceptacles was not found (figures 4, 21-26).

MICH s.n. (originally identified as Lithothamnion erubescens f. prostrate Foslie in 1901 and as L. incertum in 1904) from Bermuda, presents non-geniculate thallus attached on a rock fragment with subdichotomously
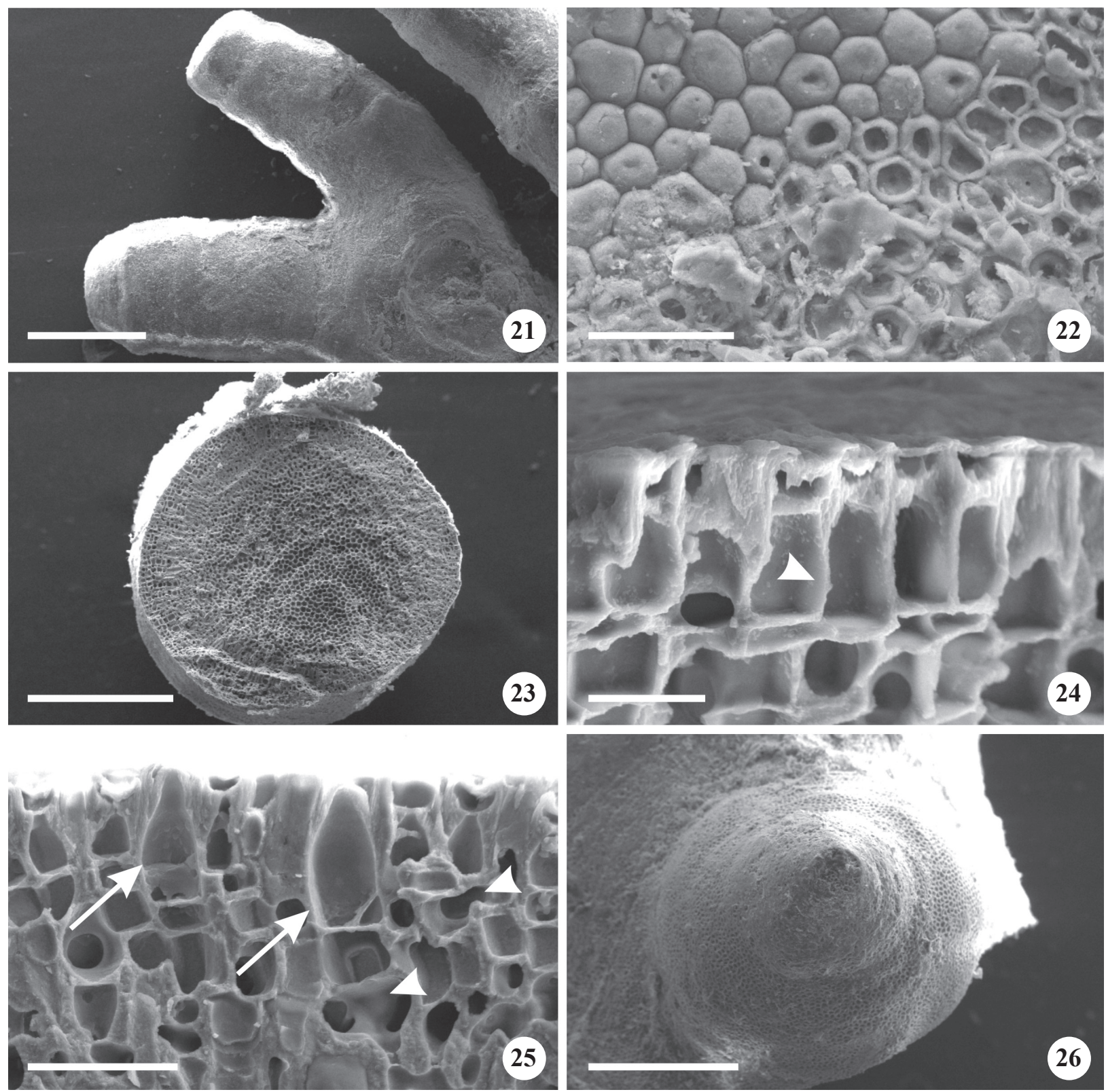

Figures 21-26. Scanning electron micrographs of MICH 18340 as Lithothamnion erubescens from Taylor's Herbarium; material from Florida. 21. Surface view of cylindrical protuberance $(B a r=1 \mathrm{~mm})$. 22. Detail of surface view of epithallial cells $(B a r=$ $50 \mu \mathrm{m})$. 23. Protuberance in transversal section $(B a r=500 \mu \mathrm{m})$. 24. Detail of a transversal section of subepithallial elongated cells (arrow head) $(\mathrm{Bar}=20 \mu \mathrm{m})$. 25. Transversal section of a portion of epithallial region showing trichocytes (arrows) and cell fusions (arrow head) $(\mathrm{Bar}=50 \mu \mathrm{m})$. 26. Surface view of uniporated conceptacle $(\mathrm{Bar}=200 \mu \mathrm{m})$. 
branched crusts, $4 \mathrm{~cm}$ high. Protuberances branched, flattened, 1-4 mm in diameter and 5-12 mm long, with frequent fusions. Epithallial cells like "Leptophythontype". Protuberances with cells of medullary filaments 7-18 $\mu \mathrm{m}$ long and 3-10 $\mu \mathrm{m}$ in diameter; cells of cortical filaments $10-23 \mu \mathrm{m}$ long and $4-10 \mu \mathrm{m}$ in diameter; subepithallial initials cells markedly longer than the subtending ones, 8-18 $\mu \mathrm{m}$ long and 3-7 $\mu \mathrm{m}$ in diameter. Epithallial cells single, oval, 2-3 $\mu \mathrm{m}$ long and 3-9 $\mu \mathrm{m}$ in diameter; isolated trichocytes present. Adjacent filaments joined by cell fusion. Secondary pit connections were not observed. Tetrasporangial conceptacle multiporate, protruding above the surrounding surface, with roofs flattened without differentiation into a peripheral rim and a central, sunken pore plate; chambers elliptical 200-354 $\mu \mathrm{m}$ in diameter and 90-180 $\mu \mathrm{m}$ high with roof or pore plate 18-38 $\mu \mathrm{m}$ thick composed of 4-6celled filaments of rounded cells; pore canals lined by 3 celled filaments with a basal cell 12-20 $\mu \mathrm{m}$ long and 3-6 $\mu \mathrm{m}$ in diameter, longer than the other roof cells. Tetrasporangia were not observed. Apical plugs that block the roof pore prior to spore release were present (figures 5, 27-30).

\section{Discussion}

According to a large number of previous studies (Chamberlain \& Irvine 1994, Chamberlain \& Keats 1994, Woelkerling 1996, Athanasiadis et al. 2004) the genus Mesophyllum is characterized by the presence of adjacent filaments joined by cell fusions, tetrasporangial multiporate conceptacles, subepithallial initials as long or longer than the cells immediately subtending them, coaxial hypothallium, male conceptacles with only unbranched spermatangial filaments and dumbbellshaped carposporangial chamber, which matches perfectly with our plants. In addition, according to Verheij (1993, 1994), Keats \& Chamberlain (1994), Ringeltaube \& Harvey (2000), Broom et al. (2008), M. erubescens is characterized by: (i.) raised tetrasporangial conceptacles; (ii.) lack of a raised rim around tetrasporangial conceptacle chamber roof; and (iii.) pore canal lined by filaments composed of cells that are similar in diameter to the cells surrounding the roof filaments, but having fewer cells and being the basal one elongated. All these characteristics were observed in our specimens as well confirming the specific identification (table 1).
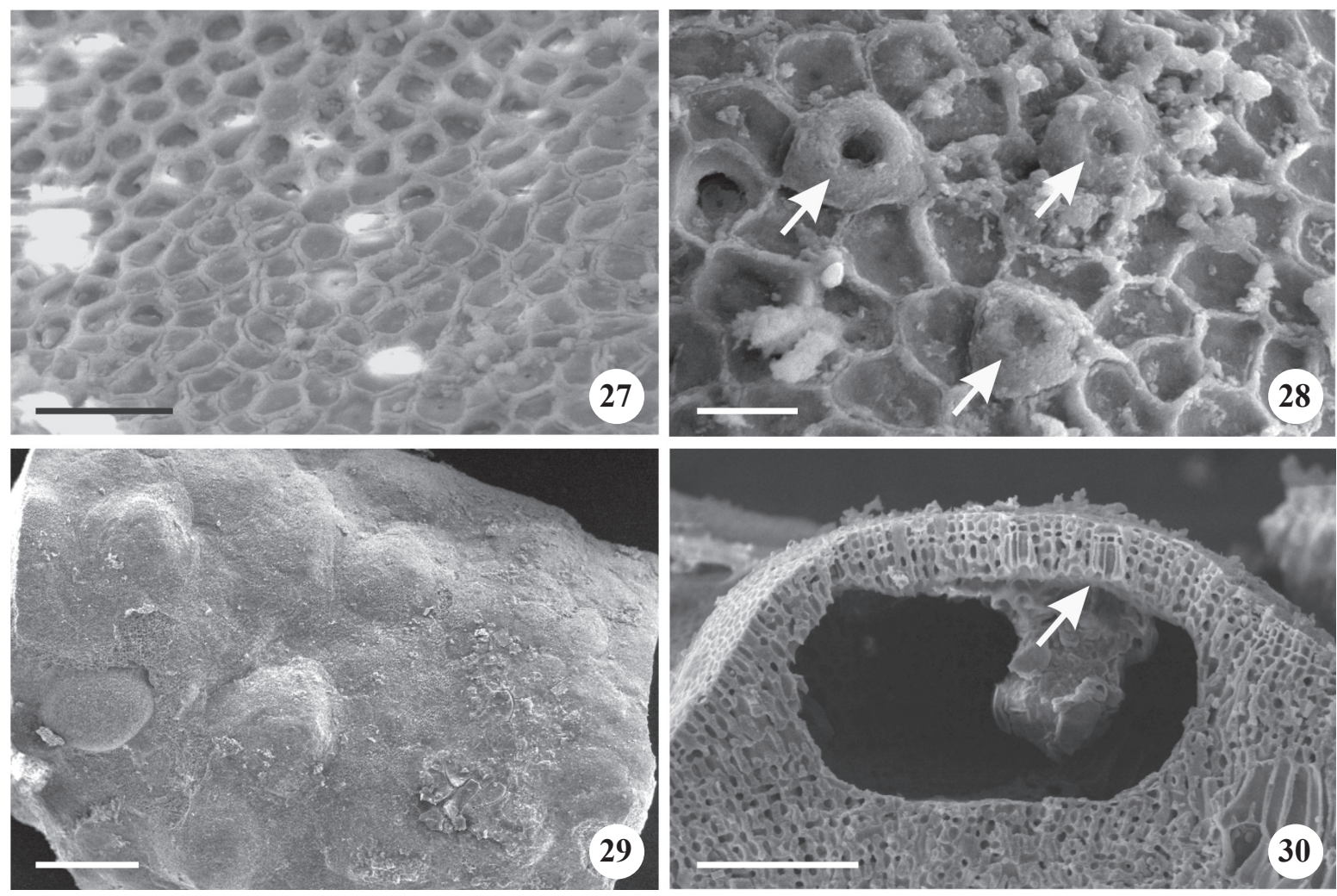

Figures 27-30. Scanning electron micrographs of MICH s.n. as Lithothamnion erubescens f. prostrate from Taylor's Herbarium; material from Bermuda. 27. Epithallial cells surface view $(B a r=20 \mu \mathrm{m})$. 28. Surface view of trichocytes (arrows) $(B a r=10 \mu \mathrm{m})$. 29. Surface view of multiporated tetrasporangial conceptacles $(\mathrm{Bar}=500 \mu \mathrm{m})$. 30. Section of multiporated tetrasporangial conceptacle, showing pore with basal elongated cells (arrow) $(\mathrm{Bar}=100 \mu \mathrm{m})$. 
Revista Brasil. Bot., V.34, n.1, p.125-134, jan.-mar. 2011

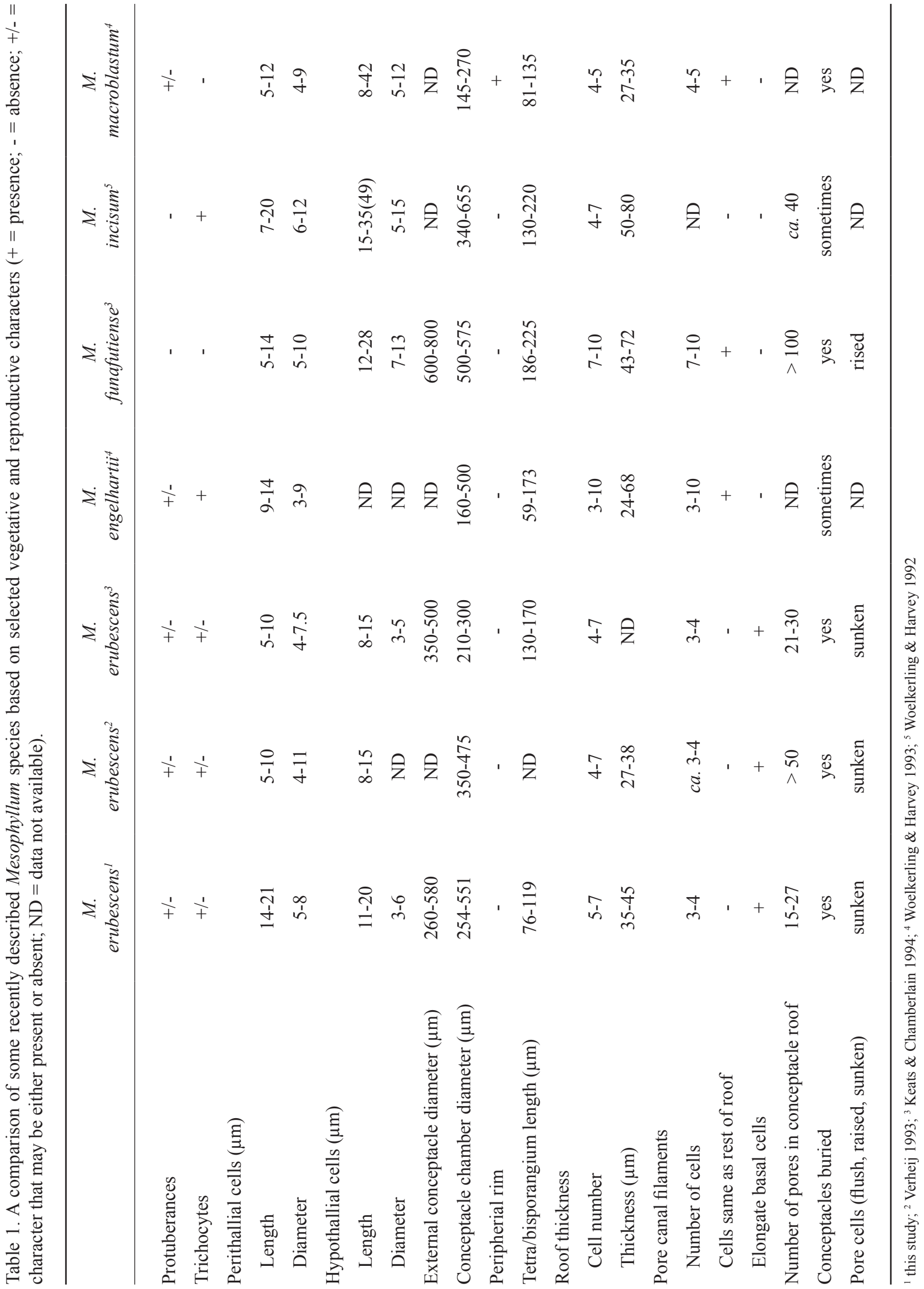


Among the other six species of Mesophyllum described to the western Atlantic, M. mesomorphum (Foslie) Adey, M. ornatum (Foslie et Howe) Athanasiadis and M. syntrophicum (Foslie) Adey are represented by crustose to foliose thallus (Athanasiadis 1999, Wynne 2005). M. mesomorphum presents smaller tetrasporangial conceptacles, whereas M. syntrophicum presents larger tetrasporangial conceptacles than observed in our specimens (Taylor 1960). According to Athanasiadis (1999), M. ornatum was originally described as a sterile variety of Lithothamnion mesomorphum Foslie; it has erect proliferations and the chamber of tetrasporangial conceptacle has a diameter compatible with our material. However, this species presents the pore canals lined by a series of small and square cells, differing in shape and size from M. erubescens.

Nunes et al. (2008) described M. erubescens to the state of Bahia, at about the midway between the type locality and our collection site, with tetrasporangial conceptacle roof 4-5 cells thick with pore canal lined by fewer cells being the basal one elongated. These resemblances reaffirm to present identification, showing that this species extends to a large stretch of coast, being tolerant to a large variation of temperature, capable to occupy tropical and warm temperate subtidal areas (Horta et al. 2001).

Among the species recently described $M$. engelhartii (Foslie) Adey (Woelkerling \& Harvey 1993, Woelkerling 1996) and M. funafutiense (Foslie) Verheij (Keats \& Chambelain 1994) present conceptacle with thicker roof and larger number of cell layers when compared to the specimens from the Arvoredo Island. Besides presenting thicker roof, $M$. incisum (Foslie) Adey is characterized by pore canal lined by filaments that differ from those of the surrounding roof cells in being narrower, while M. erubescens presents elongate basal cells of these filaments (Keats \& Maneveldt 1997). Differently from our material, M. macroblastum (Foslie) Adey (Woelkerling \& Harvey 1993) presents tetrasporangial conceptacle roof with peripheral rim and pore canals bordered by cells that are similar in size and shape to the other roof cells (table 1).

The free forms of Mesophyllum aemulans (Foslie et Howe) Adey and M. floridanum (Foslie) Wynne present surface elevations knob or wartlike (Taylor 1960), but not obviously branched as in our material. According to Printz (1929) the superficial sporangial conceptacle in those species are similar to that found in M. erubescens, but as already remarked by Woelkerling et al. (1993), the above morphological characteristics are not sufficient to distinguish those species, and a critical analysis of those taxa are needed. Besides, Broom et al. (2008), based on molecular analysis, found that there is a high genetic variability in the Corallinales species, forming clades that cannot be seen with traditional taxonomy. Based on that we anticipate substantial nomenclatural changes when more material is adequately studied.

The analysis of Taylor's material reveal that the identification of Florida specimens as $M$. erubescens could be correct due to the presence of subepithallial elongated cells and the characteristic shape of the uniporated conceptacle, also present in the female specimens from Brazil. However, the analysis of tetrasporophytic material from Florida is necessary to corroborate the identification.

Lithothamnion erubescens f. prostrata Foslie from Bermuda (Foslie 1901), identified by Foslie (1904) as Lithothamnion incertum Foslie, and presented by Taylor (1960) under this denomination, despite having compressed branches slightly tapering to rounded ends, has pore canals lined by three celled filaments with a basal cell longer than the other roof cells. According to Keats \& Chamberlain (1994) it reveals that the material identified by Taylor as L. incertum should be referred as $M$. erubescens.

The presence of the epithallial cell like Leptophytontype in the Taylor's materials, while in the Brazilian and South African material was observed Phymatolithontype, can be derived of differences inherent to years under dry herbarium conditions. Similar differences can be observed in the analysis of the type material of $M$. erubescens presented by Keats \& Chamberlain (1994, figures 13 and 26).

The lack of critic taxonomic information in reference works, such as the one of Taylor (1960), reinforces the need to revise old identifications of the crustose coralline red algae, especially in areas where this group is so poorly studied, such as the Brazilian Coast and western Atlantic.

Acknowledgments - The first author is grateful to CNPq for providing grants. Rafael Riosmena-Rodrigues acknowledge CONACYT for the grant 34118-V. We also thank the editorial board for the important contributions on the manuscript's final version review.

\section{References}

ADEY, W.H. 1970. A revision of the Foslie crustose coralline herbarium. Norske Vindensk. Kongelige Norske Vindenskabers Selskabs Skrifter 1:1-46. 
ATHANASIADIS, A. 1999. Mesophyllum macedonis nov.sp. (Rhodophyta, Corallinales), a putative Tethyan relic in the North Aegean Sea. European Journal of Phycology 34:239-252.

ATHANASIADIS, A., LEBEDNIK, P.A. \& ADEY, W.H. 2004. The genus Mesophyllum (Melobesioideae, Corallinales, Rhodophyta) on the northern Pacific coast of North America. Phycologia 43:126-165.

BROOM, J.E.S., HART, D.A., FARR, T.J., NELSON, W.J., NEILL, K.F., HARVEY, A.S. \&WOELKERLING, W.J. 2008. Utility of psbA and nSSU for phylogenetic reconstruction in the Corallinales based on New Zealand taxa. Molecular Phylogenetics and Evolution 46:958973.

CABIOCH, J. \& MENDOZA, M.L. 1998. Mesophyllum alternans (Foslie) comb. nov. (Corallinales, Rhodophyta), a mediterraneo-atlantic species, and new considerations on the Lithothamnion philippii Foslie complex. Phycologia 37:208-221.

CHAMBERLAIN, Y.M. 1993. Observations on the crustose coralline red alga Spongites yendoi (Foslie) comb. nov. and Lithophyllum natalense Foslie. Phycologia 32:100115.

CHAMBERLAIN, Y.M. 2000. Mesophyllum capense (Rosanoff) comb. nov. (Rhodophyta, Corallinaceae) from South Africa. Cryptogamie Algologie 21:365379.

CHAMBERLAIN, Y.M. \& IRVINE, L.M. 1994. Melobezioideae Bizzozero. In Seaweeds of the British Isles, v.1. Rhodophyta, Part 2B, Corallinales, Hildenbrandiales (L.M. Irvine \& Y.M. Chamberlain, eds.). Her Majesty's Stationary Office and The Natural History Museum, London. p.159-234

CHAMBERLAIN, Y.M. \& KEATS, D.W. 1994. Three melobesioid crustose coralline red algae from South Africa: Leptophytum acervatum (Foslie) comb. nov., L. foveatum sp. nov. and L. ferox (Foslie) comb. nov. Phycologia 33:111-133.

DICKIE, G. 1874. Enumeration of algae collected at Fernando de Noronha. Journal of the Linnean Society (Botany) 14:363-365.

FIGUEIREDO, M.A.O. \& STENECK, R.S. 2002. Floristic and ecological studies of crustose coralline algae on Brazil's Abrolhos reefs. In Proceedings of the $9^{\text {th }}$ International Coral Reef Symposium, Bali, p.493-498.

FOSLIE, M. 1900. Revised systematical survey of the Melobesieae. Kongelige Norske Vindenskabers Selskabs Skrifter 5:1-22.

FOSLIE, M. 1901. New Melobesieae. K. Norske Vindensk. Kongelige Norske Vindenskabers Selskabs Skrifter 6: 2-24.

FOSLIE, M. 1904. Die Lithothamnien des Adriatischen Meeres und Marokkos. Wissenschaftliche Meeresuntersuchungen Abteilung Helgoland, Neue Folge 7:1-40.
HARVEY, A.S., WOELKERLING, W.J. \& MILLAR, A.J.K. 2003. An account of the Hapalidiaceae (Corallinales, Rhodophyta) in south-eastern Australia. Australian Systematic Botany 16:647-698.

HEMSLEY, W.B. 1885. Report on botany of Bermuda and various other islands of the Atlantic and Southern oceans. In Report on the science results of the voyage of H.M.S. Challenger. Botany. (C.W. Thonson \& J.Murray, eds.) Her Majesty's Stationary Office, London v.1, i,ii, p.104-128; v.2, p.1-135, v.3, p.1-299, (bound in v.1).

HORTA, P.A. 2002. Bases para a identificação das coralináceas não articuladas do litoral brasileiro - uma síntese do conhecimento. Biotemas 15:7-44.

HORTA, P.A., AMANCIO, E., COIMBRA, C.S. \& OLIVEIRA, E.C. 2001. Considerações sobre a distribuição e origem da flora de macroalgas marinhas brasileiras. Hoehnea 28:243-265.

KEATS, D.W. \& CHAMBERLAIN, Y.M. 1994. Two melobesioid coralline algae (Rhodophyta, Corallinales), Mesophyllum erubescens (Foslie) Lemoine and Mesophyllum funafutiense (Foslie) Verheij from Sodwana Bay, South Africa. South African Journal of Botany 60:175-190.

KEATS, D.W. \& MANEVELDT, G. 1997. First report of the melobesioid alga (Corallinales, Rhodophyta) Mesophyllum incisum (Foslie) Adey in South Africa. South African Journal of Botany 63:201-209.

KIM, J.H., CHUNG, H., CHOI, D.S. \& LEE, I.K. 2004. A new melobesioid alga Synarthrophyton chejuensis sp. nov. (Corallinales, Rhodophyta), including comparison with Mesophyllum cystocarpideum. Phycologia 43:501-520

LEMOINE, ME.P. 1928. Un nouveau genre de Mélobésiées: Mesophyllum. Bulletin Societé Botanique de France 75:251-254.

LITTLER, M.M. \& LITTLER, D.S. 2000. Caribbean reef plants. Off Shore Graphics Inc., Washington.

MOURA, C.W.N., KRAUS, J.E. \& CORDEIROMARINHO, M. 1997. Metodologia para obtenção de cortes histológicos com historresina e coloração com azul de toluidina para algas coralináceas (Rhodophyta, Corallinales). Hoehnea 24:17-27.

MURRAY, G. 1893. A comparison of the marine floras of the warm Atlantic, Indian Ocean and the Cape of Good Hope. Phycological Memoirs, London.

NUNES, J.M.C., GUIMARÃES, S.M.P.B., DONANGELO, A., FARIAS, J. \& HORTA, P.A. 2008. Aspectos taxonômicos de três espécies de coralináceas não geniculadas do litoral do estado da Bahia, Brasil. Rodriguésia 59:75-86.

OLIVEIRA FILHO, E.C. 1974. An annotated list of the Brazilian seaweeds in Dickie's herbarium. Journal of the Linnean Society (Botany) 69:229-238.

OLIVEIRA FILHO, E.C. 1977. Algas marinhas bentônicas do Brasil. Tese de livre docência, Universidade de São Paulo, São Paulo. 
PEREIRA, S.M.B., CARVALHO, M.F.O.,ANGEIRAS, J.A.P., PEDROSA, M.E.B., OLIVEIRA, N.M.B., CARNEIRO, J.M.T., GESTINARI, L.M.S., CONCENTINO, A.M., NASCIMENTO, P.R.F. \& RODRIGUES, D. 2002. Algas marinhas bentônicas do Estado de Pernambuco. In Diagnóstico da biodiversidade de Pernambuco (M. Tabarelli \& J.M.C. Silva, eds.). Secretaria de Ciência, Tecnologia e Meio Ambiente, Fundação Joaquim Nabuco, Editora Massangana, Recife, v.1, p.97-124.

PRINTZ, H. 1929. M. Foslie-Contributions to a monograph of the Lithothamnia. Kongelige Norske Vindenskabers Selskabs Skrifter Museet, Trondhjen.

RINGELTAUBE, P. \& HARVEY, A. 2000. Non-geniculate coralline algae (Corallinales, Rhodophyta) on the Heron Reef, Great Barrier Reef (Australia). Botanica Marina 43:431-454.

TÂMEGA, F.T.S. \& FIGUEIREDO, M.O. 2005. Distribuição das algas calcárias incrustantes (Corallinales, Rhodophyta) em diferentes habitats na Praia do Forno, Armação dos Búzios, Rio de Janeiro. Rodriguésia 56:123-132

TAYLOR, W.R. 1960. Marine algae of the eastern tropical and subtropical coasts of the Americas. University of Michigan Press, Michigan.

VERHEIJ, E. 1993. Marine plants on the reefs of the Spermonde Archipelago, SW Sulawesi, Indonesia: aspects of taxonomy, floristics, and ecology. Rijksherbarium/Hortus Botanicus, Leiden.

VERHEIJ,E. 1994. Nongeniculate corallinaceae(Corallinales, Rhodophyta) from the Spermonde Archipelago, SW Sulawesi, Indonesia. Blumea 39:95-137.
VILLACA, R., PEDRINI, A., PEREIRA, S.M.B. \& CREED, M.F. 2006. Flora marinha bentônica das ilhas oceânicas brasileiras. In Ilhas oceânicas brasileiras. Da pesquisa ao manejo (R.J.V. Alves \& J.W. de A. Castro, eds.). Ministério do Meio Ambiente, Brasília, v.5, p.105-146.

WOELKERLING, W.J. 1988. The coralline red algae: an analysis of the genera and subfamilies of nongeniculate Corallinaceae. British Museum (Natural History) \& Oxford University Press, London and Oxford.

WOELKERLING, W.J. 1993. Type collections of Corallinales (Rhodophyta) in the Foslie Herbarium (TRH). Gunneria 67:1-289.

WOELKERLING, W.J. 1996. Ordem Corallinales. In The Marine Benthic Flora of the Southern Australia. Part III B. Gracilariales, Rhodymeniales, Corallinales and Bonnemaisoniales (H.B.S. Womersley, ed.). Australian Biological Resources Study, Canberra.

WOELKERLING, W.J. \& HARVEY, A. 1992. Mesophyllum incisum (Corallinaceae, Rhodophyta) in southern Australia: implications for generic and specific delimitation in the Melobesioideae. British Phycological Journal 27:381-399.

WOELKERLING, W.J. \& HARVEY, A. 1993. An account of southern Australian species of Mesophyllum (Corallinaceae, Rhodophyta). Australian Systematic Botany 6:571-637.

WOELKERLING, W.J., IRVINE, L.M. \& HARVEY, A.S. 1993. Growth-forms in non-geniculate coralline red algae (Corallinales, Rhodophyta). Australian Systematic Botany 6:277-293.

WYNNE, M.J. 2005. A checklist of benthic marine algae of the tropical and subtropical western Atlantic: second revision. Nova Hedwigia 129:1-152. 